\title{
Respiration in the \\ Invertebrates
}




\section{MACMILLAN STUDIES IN GOMPARATIVE ZOOLOGY}

General Editors: J. B. Jennings and P. J. Mill, University of Leeds

Each book in this series will discuss an aspect of modern zoology in a broad comparative fashion. In an age of increasing specialisation the editors feel that by illustrating the relevance of zoological principles in a general context this approach has an important role to play. As well as using a wide range of representative examples, each book will also deal with its subject from a number of different viewpoints, drawing its evidence from morphology, physiology and biochemistry. In this way the student can build up a complete picture of a particular zoological feature or process and gain an idea of its significance in a wide range of animals. 


\section{Respiration \\ in the \\ Invertebrates}

$$
\text { P. J. MILL, B.Sc., Ph.D }
$$

Lecturer in Zoology, The University of Leeds 
(C) P. J. Mill 1972

All rights reserved. No part of this publication may be reproduced or transmitted, in any form or by any means, without permission.

First published 1972 by THE MAGMILLAN PRESS LIMITED London and Basingstoke Associated companies in New York Toronto Dublin Melbourne Johannesburg and Madras

SBN 333134435 (cased) I371 6 (paper)

Library of Congress catalog card number 72-90019 ISBN 978-0-333-13711-6 ISBN 978-1-349-15478-4 (eBook) DOI 10.1007/978-1-349-15478-4 
To my wife, Gillian 


\section{Preface}

The intention of this book is to provide the undergraduate with a comprehensive account of invertebrate respiration from both physiological and structural viewpoints; however, much information is included that will prove valuable additional reading for Advanced level students. The subject is treated in a comparative way, rather than by presenting the reader with a series of chapters working through each group of animals in turn.

All animals require a supply of energy, both for actual physical activity and for the synthesis of protoplasmic compounds from the raw materials provided by the breakdown of their food. In some animals, such as certain parasites, this energy is provided anaerobically, that is to say without the involvement of oxygen as a hydrogen acceptor. However, the vast majority obtain their energy mainly from aerobic processes requiring the utilisation of atmospheric oxygen.

We may consider aerobic respiration as being composed of several distinct phases:

(a) The uptake of oxygen from the surrounding medium.

(b) The transport of this oxygen to the tissues.

(c) The production of energy (intracellular respiration).

(d) The removal of waste products (e.g. carbon dioxide) from the tissues.

(e) The elimination of these waste products from the animal. The first chapter deals with general considerations, particularly the need for the development of specialised respiratory structures. The different structural devices involved in oxygen uptake and the elimination of carbon dioxide from the body are dealt with in the next three chapters. The transport of oxygen and carbon dioxide provides the basis for chapters five and six, while chapter seven is devoted to intracellular respiration. The final chapter is concerned with the nervous control of respiration. An appendix is provided with a synopsis of the classificatory system used; and suggestions for further reading are contained in the bibliography. 


\section{Acknowledgements}

I would like to thank all those who have helped during the various stages in the preparation of this book. In particular I would like to thank my wife for her encouragement throughout this period and for correcting and commenting on the final text, and also Drs. E. Broadhead and J. B. Jennings who both read the first draft and made a number of valuable suggestions.

Several figures have been reproduced from other publications with the kind permission of the authors and publishers. They are as follows:

Figure 3.6, Dr. R. C. Newell and Logos Press; figure 4·6, Pergamon Press; figures $4 \cdot 12,4 \cdot 13$ and $4 \cdot 15$, Professor H. E. Hinton, the Marine Biological Association, the Royal Entomological Society, Academic Press and Cambridge University Press; figure 5.I, Dr. E. F. J. van Bruggen and Academic Press; figure 6.I, Drs. J. B. Jennings and R. Gibson and Pergamon Press; figures $8 \cdot 1,8 \cdot 2,8 \cdot 4,8 \cdot 6,8 \cdot 7$ and $8 \cdot \mathrm{II}$, Cambridge University Press; figure $8 \cdot 12$, Drs. T. Myers and E. Retzlaff and Pergamon Press; figure 8. I3, Dr. R. D. Farley and Professors J. F. Case and K. D. Roeder and Pergamon Press; figure 8.I4, Dr. R. D. Farley and Professor J. F. Case and Pergamon Press; figures $8 \cdot 15$ and $8 \cdot 17 b$, Dr. P. L. Miller, Cambridge University Press and Academic Press; figures 8. I6 and 8.20, Professor G. Hoyle and Pergamon Press; figures 8. I $7 a$ and 8.18, Professor J. F. Case and Pergamon Press.

My thanks are also due to Drs. E. F. J. van Bruggen and R. E. Weber for sending me electron micrographs for figure $5 \cdot \mathrm{I}$.

Finally I wish to thank all those whose figures I have redrawn, the details of which will be found in the appropriate legends. 


\section{Contents}

PREFACE

ACKNOWLEDGEMENTS

I. Introduction I

2. Gills, Podia and Papulae I4

3. Lungs and Respiratory Trees 64

4. Tracheal Systems 77

5. Respiratory Pigments and the Transport of Respiratory Gases $\quad 100$

6. Circulatory Systems $\quad{ }^{136}$

7. Intracellular Respiration I6 I

8. Control Mechanisms I 7 I

CLASSIFICATION $\quad 199$

BIBLIOGRAPHY 201

INDEX 203 